\section{УДК 159.9:316.6 doi: $10.15330 / p s p .24 .7-16$}

Лариса Заграй

\title{
ТЕМАТИЧНИЙ АНАЛІЗ ЯК ЯКІСНИЙ МЕТОД У ФЕМІНІСТИЧНИХ ДОСЛІДЖЕННЯХ
}

У статті розглядається проблема дослідження гендерного досвіду особистості. Розкривається питання необхідності нової методології, теорії пізнання гендеру. Феміністична методологія, зокрема постфеміністична трактується як альтернативна методологія дослідження гендерного досвіду особистості. Розглядаються чотири епістемологічні вектори - феміністичний емпіризм, позиціонізм, постмодернізм і соціальний конструкиіонізм. Для дослідження багатогранності, неоднорідності та множинності досвіду найбільш придатним визначається соиіально-конструкиіоністський вектор. Актуалізується проблема застосування якісних методів у феміністичній методологї як основних інструментів дослідження гендерного досвіду. Окреслюється тематичний аналіз як один із провідних якісних методів дослдження досвіду у соціально-конструктивістській парадигмі.

Ключові слова: тематичний аналіз, якісний метод, аналіз якісних даних, феміністична методологія, епістемологія, гендерний досвід.

The article is devoted to the description of feminist methodology and qualitative method of thematic analysis. The relevance of the feminist methodology of research as an alternative in the study of women's experience, gender experience of the personality is revealed. In this article, I argue that it offers an accessible and theoretically-flexible approach to analysing qualitative data. Feminist researchers justify the need to apply qualitative research methods to the research practice needs. The goal is to justify the thematic analysis use as a qualitative method for individual gender experience study. Female experience was interpreted by feminists as heterogeneous and plural one. It includes three dimensions: 1) experience is specific for women unlike men; 2) the experience of women members who belong to the movement against discrimination based on sex; 3) the experience of women who belong to the second wave generation of the feminist movement.Thematic analysis is widely-used qualitative analytic method within psychology. Thematic analysis is widely used, but there is no clear agreement about what thematic analysis is and how you go about doing it. I briefly describe how to use thematic analysis in psychology. Thematic analysis involves a number of choices which are often not made explicit (or are certainly typically not discussed in the method section of papers), but which need explicitly to be considered and discussed.The technology of thematic analysis in the research of gender schemes of the experience of men and women is presented. The main stages of application of thematic analysis in the study of the gender experience of the personality are described. I outline the disadvantages and advantages of thematic analysis.

Keywords: thematic analysis, qualitative method, analysing qualitative data, feminist methodology, epistemology, gender experience.

Постановка проблеми. Дослідження гендерного досвіду особистості можливе при умові врахування його багатогранності, унікальності, динамічності. Чи існує методологія, яка створює підгрунтя для дослідження гендерного досвіду? Найбільш придатною методологією для дослідження досвіду гендеру особистості є феміністська, зокрема постфеміністська. У межах постмодерністського фемінізму фемінізм набув статусу методології, яка критикує

(C) Заграй Л., 2019.

Збірник наукових праць: психологія. 
наукову раціональність і об'єктивність, оголошуючи їх такими, що обслуговують чоловічу науку, актуалізує проблему обмеженості знання, представленого в соціальній теорії виключно чоловіками, їх системою цінностей, чоловічим поглядом на світ («адроцентрична картина світу»), чоловічими засобами вираження знання («фалогоцентризм»). Заперечуючи колишню раціональність, постмодерністський фемінізм пропонує враховувати особливості суб'єкта пізнання певної статі, його (ii) ціннісні орієнтації. Постфемінізм трактується як відмова від спроби фемінізму створити місце для жінки поза патріархальною системою та бажання знайти власне місце. Постфеміністки здійснюють спроби писати про свою жіночу сутність (womanhood), на відміну від традиційних феміністок, які продовжують суперечки про природу патріархальної суспільної системи. Отже саме феміністська методологія, зокрема постфеміністська враховує особливість гендерного досвіду людини. Вона робить акцент на почуттях, бажаннях, інтересах суб'єкта. Феміністську методологію вважають альтернативною, у якій фокусується увага на жіночому досвіді і проблематизується вибір методів дослідження його. Оскільки предметом дослідження у феміністичному дослідженні $є$ досвід жінок, то і така специфіка предмета буде визначати вибір метода дослідження, зокрема акцентування уваги на якісних методах. Існують численні якісні методи дослідження, серед яких вагоме місце займає тематичний аналіз, про особливості застосування якого обмаль інформації.

Мета - обгрунтувати застосування тематичного аналізу як якісного методу дослідження жіночого досвіду. Завдання статті - розкрити феміністичну, постфеміністичну методологію як альтернативну методологію дослідження у психології, яка створює можливості вивчення досвіду гендеру особистості; описати тематичний аналіз як метод дослідження гендерного досвіду особистості.

Аналіз останніх досліджень. Жіночий досвід був осмислений феміністками як неоднорідний і множинний. Він включає у себе три виміри: 1) досвід специфічний для жінок на відміну від чоловіків; 2) досвід жінок - учасниць руху проти дискримінації за ознакою статі; 3) досвід жінок-дослідниць, які належать до покоління другої хвилі феміністського руху (J. Hyde, 1996; M. Matlin, 1996; C. Percy, 1998; J. Kitzinger, 1992; S. Wilkinson and C. Kitzinger, eds., 1993; M. Gergen, 2001; L. Stanley and Wise, S. Breaking, 1993; A. H. Eagly, A. Eaton, S. M. Rose, S. Riger \& M. C. McHugh, 2012; S. N. Hesse-Biber? 2013). Досвід жінок пов'язаний із сім'єю, народженням дітей, емоціями, сексуальністю, самореалізацією у професійній і приватній сферах тривалий час не був предметом дослідження і тільки феміністська епістемологія бере такі аспекти у центр уваги своїх досліджень (C. Gilligan, 1993). Щодо досвіду участі жінок у жіночих рухах, то феміністки стали особливо чутливими до практик виключення, замовчування, табуювання соціальних меншин у соціальному пізнанні. Феміністська методологія стає когнітивним елементом боротьби за рівні можливості для чоловіків і жінок, що належать до різних соціальних категорій. Відбувається переосмислення жіночого протестного руху і гендерної нерівності 
у всіх сферах життя, реконструюється епістемологія як основа соціальної системи і патріархату.

Феміністки проблематизують свій професійний досвід і виявляють невідповідність їх особистого досвіду, що на думку психологів призводить до дисгармоній, внутрішніх конфліктів та невротичних розладів. Таку невідповідність Д. Сміт пояснює структурно-функціональним аналізом, відповідно до якого існує розподіл статевих ролей і виконання жінкою експресивної, а чоловіком інструментальної ролей (Д. Смит, 2000. С. 32). Такий розподіл статевих ролей оголошується нормою і умовою стабільності системи. Однак такі положення не відповідають знанням і досвіду жінок, які діють у публічній сфері і виконують інструментальну роль. Таким чином, багатомірний жіночий досвід породжує потребу у формуванні нової теорії пізнання, новій методології і нових дослідницьких техніках, оскільки класичні моделі виявилися гендерно нечутливими.

У відповідь на окреслену проблему протягом двадцяти років у рамках феміністської теорії сформувалися чотири епістемологічних вектори - феміністичний емпіризм, позиціонізм, постмодернізм і соціальний конструкціонізм. Емпіризм як феміністська епістемологія - це дослідницька стратегія включення жінок у позитивістський дискурс (Sandra Harding, 1987. С. 1-14), який досвід жінок не враховує і вимагає застосування об'єктивних методів і підходів у дослідженні жіночих проблем. У феміністичному позиціонізмі проблематизується жіноча ідентичність, жіночий досвід, який можна вивчати тільки 3 позиції жінки-дослідниці, яка володіє специфічною дослідницькою стратегією (Sandra Harding, 2016; Дороті Смід, 2000). Однак прихильницями теорії позиції не враховуються відмінності між жінками, наприклад, кольоровими, з різним соціальним статусом чи жінки, які мають різний рівень освіти і доступ до матеріальних та соціальних благ і відповідно, різний досвід. Постмодерністська методологія ставить під сумнів об'єктивність отримання будь-якого знання. Дискурс визначає об'єктивність знання, окреслюючи об'єкт аналізу для подальшого осмислення і вибору інструментів пізнання. Таким чином, істинності набуває те, що дискурс дозволяє означувати як істинне. Існуючий панівний владно-підвладний дискурс, що породжує гендерну нерівність потребує деконструкції, яка можлива через деконструкцію індивдуального досвіду. Відповідно прихильниці постмодерністської методології вважають дискурсивний аналіз провідним у феміністичних дослідженнях (Judith Butler, 1990). На відміну від представників теоpiї позиції, конструктивісти стверджують, що не існує особливої феміністичної науки й універсального знання, оскільки будь-яке знання контекстуальне і $€$ результатом досвіду. Знання є когнітивною практикою, тому у кожній конкретній ситуації потрібно аналізувати, хто вивчав, що, коли і чому. Прихильники цього підходу заперечують можливість проведення об'єктивного дослідження єдиного досвіду жінок. Вони звертають увагу на множинний досвід жінок, які знаходяться на різних позиціях (M. Gergen, 2001). Соціокультурні контексти породжують уявлення про владу і домінування, визначаючи ієрархію груп i приписуючи їм відповідний статус. Соціальні і політичні контексти дуже важливі в інтерпретації конкретних жіночих досвідів (S. N. Hesse-Biber, 2013). 
Наприклад, становище гетеросексуальної європейки жінки середнього класу 3 вищою освітою і неписьменної африканки досить різне, тому неможливо говорити про спільність досвіду та належність до єдиної категорії дослідження «жінки». Тому конструктивістська феміністична методологія виходить із фрагментарності досвідів і позицій жінок залежно від вікових, сексуальних, расових, політичних та інших характеристик. На перетині цих характеристик формуються локалізовані групові досвіди, які i структурують знання із психології гендеру.

Виклад основного матеріалу. Відмовляючись від єдиної і неподільної категорії «жінки», прихильники конструктивістського підходу зосереджують увагу на конкретному досвіді - наприклад, жінок, що пережили насильство; жінок, чоловіки, яких беруть участь у військових діях; жінок, які переживають конфлікт кар'єрних домагань і потреб сім'ї тощо. Між такими різними досвідами складно знайти щось спільне. Однак усередині кожної із категорій існує інтерсуб'єктивний досвід, який об'єднує певну групу жінок. Таким чином, завданням феміністичного дослідження є реконструювання такого досвіду у різних контекстах, створених із різних розповідей і різних репрезентацій, що $\epsilon$ можливим за умови застосування якісних методів. Проблема конструктивістської методології полягає у тому, як забезпечити валідність, надійність і науковість отриманого знання.

Феміністські дослідниці стверджують, що існують не особливості метода дослідження, а особливості його застосування. Всі діагностичні методи (опитувальники, інтерв'ю, спостереження, інтерпретація офіційних статистичних даних, історичних документів, біографій) на перший погляд однакові, які дозволяють слухати, фіксувати те, що люди скажуть, що роблять, аналізувати відповідні тексти, документи. Проте як зазначає С. Хардінг, феміністичне дослідження має свою специфіку, яка передбачає: жінок».

1. «Альтернативне походження проблем, які стосуються передусім

2. Формулюванням «альтернативних пояснювальних гіпотез».

3. Формулюванням «нових цілей дослідження», які передбачають усвідомлення жінками своєї ролі у перетворенні гендерних відносин.

4. Зміною природи відносин між суб'єктом і об'єктом пізнання (Sandra Harding, 2016).

Феміністична перспектива дослідження передбачає відхилення не тільки жіночої традиційної ролі, але й попередніх методів дослідження, надаючи перевагу якісним методам. Феміністкські дослідниці обгрунтовують необхідність застосування якісних методів дослідження потребами дослідницької практики: якщо необхідно з'ясувати значення відповіді опитуваної; уточнити аспекти думок досліджуваних; виявити вплив на формування уявлень, переживань, ставлень; проаналізувати складні установки, переконання; вийти на мотиваційні інтерпретації; здійснити інтерпретацію статистичних взаємозв'язків, перш за все випадків, які відхиляються від середньостатистичної норми; провести аналіз ефектів і процесів набуття індивідуального досвіду як реакції на певні ситуації; 
виявити межі репертуару можливостей індивіда (M. Kohli, G. Roberts, (Hg), 1984). Отже, відкриті якісні методи призначені для того, щоб створити можливість респондентам максимально повно висловити релевантні їм суб'єктивні інтерпретації. Однак, як зазначає Колі, не йдеться про те, що отримані в інтерв'ю дані автентично представляють респондента, що потрібно просто зафіксувати всі його висловлювання, думки. Можливості контролю за вимірювальним процесом полягають у підтримуванні інтерсуб'єктивності, яка трактується як баланс між перспективою учасників інтерв'ю й умовами контексту і досягається участю декількох інтерпретаторів (M. Kohli, G. Roberts, 1984). Валідність у якісному дослідженні можна розуміти дещо інакше - за допомогою терміна «досвід», що ближче знаходиться до кількісної методології: збір даних можна вважати валідним тоді, коли він дозволяє «підібратися» до реального досвіду і розповідей про нього, коли інтерпретація цього досвіду дає можливість вибудовувати елементи теорії. Надання переваги у жіночих дослідженнях якісним методам пояснюють затребуваністю самого предмету дослідження - сімейні і професійні взаємозв'язки життя жінок, ключові події у їхніх біографіях чи суперечності жіночої ідентичності, наявність у жіночих біографіях дискримінаційних практик - все це підштовхує їх до застосування якісних методів (F. Koch, 1995. C. 30).

Якісні методи застосовують у тих випадках, коли необхідно з'ясувати контекст отриманих даних щодо становища жінок, а також закономірності історій життя і проблематики життєвого світу жінки / чоловіка, процесу конструювання соціальної статі (B. Briick, 1992). Наприклад, для того, щоб відстежити мікропроцеси створення гендеру, дослідниці / досліднику необхідно емпірично й аналітично проникнути у повсякденність і відповісти на запитання, як конкретні, ситуаційно пов'язані практики інтеракції продукують відтворювані структури. Таким чином, це дозволяе зрозуміти більш загальні макросоціальні запитання: як досягнути засвоєння структури авторитет-підпорядкування як засобу відтворення соціального панування, яка «соціальна агентура» цього опосередкування, як двостатева культурна система інституалізується через повсякденну практику взаємодії чоловіків і жінок, як у цій практиці відбувається формування біографічного досвіду. Такі непрості запитання вимагають інтегративних, міждисциплінарних підходів і методів.

На мою думку, одним 3 найбільш ефективних якісних методів можна вважати тематичний аналіз. Тематичний аналіз слід розглядати як основний метод якісного аналізу. Це якісний метод аналізу, який забезпечує досліднику основні навички, які необхідні для проведення багатьох інших форм якісного аналізу. Даний метод ідентифікуе «тематичні значення» як одну з небагатьох спільних загальних навиків по якісному аналізу (Холлоуей і Тодрес, 2003, C. 347); з цієї причини Бойцазіс (1998) характеризує його не як специфічний метод, а як інструмент для використання різних методів. Аналогічним чином Райан і Бернард (2000) визначають тематичне кодування як процес, що відбувається в рамках «основних» аналітичних традицій (таких як обгрунтована теорія), а не як конкретний підхід. Як зазначають Браун і Кларк, тематичний 
аналіз слід розглядати як самостійний метод, який має всі необхідні характеристики і дозволяє досліджувати суб'єктивний досвід особистості зокрема (Braun Virginia, Clarke Victoria, 2006).

Тематичний аналіз сумісний 3 есенціалістськими та конструкціоністськими парадигмами в рамках психології. Однак треба ураховувати, що результат та фокус дослідження будуть відрізнятися. У межах есенціалістського підходу у центрі уваги є досвід, мотивація, цілепокладання та смисложиттєві орієнтири. Із соціально конструкціоністської перспективи досвід, смисложиттєва спрямованість особистості є соціально сконструйованими (Burr, 1995). Тому тематичний аналіз, що використовується в межах конструктивістської парадигми, не зосереджується на індикаторах індивідуальної психології, а спрямований на з'ясування соціально-культурних контекстів, у межах яких потрібно вивчати досвід особистості. А це у свою чергу, дозволяє визначати не сам досвід, а способи, особливості його конструювання, знання яких дозволяє вести мову про реконструювання травматичного, негативного чи диструктивного досвідів. Отже, тематичний аналіз у руслі конструктивізму зосереджує увагу на більш «латентних» темах, які можуть дублюватися навіть із аналізом дискурсу.

С два основні способи вибору матеріалу для тематичного аналізу. Поперше, набір даних може бути взятий з одного або кількох джерел. Так, наприклад, це можуть бути інтерв’ю, матеріали соціальних мереж, бесід, анкетувань тощо. По-друге, набір даних може бути ідентифікований, вибраний на підставі певного аналітичного інтересу у відповідній темі даних. Важливим поняттям у тематичному аналізі $\epsilon$ «елемент», що використовується для позначення кожного окремого об'єкта зібраних даних, які разом складають набір даних, зокрема елементом може бути індивідуальне інтерв’ю (матеріал інтерв'ю), конкретний веб-сайт, матеріал психотерапевтичної роботи, документальний фільм тощо. Витяг даних може бути кодованим фрагментом, який ідентифіковано у рамках елемента даних та вилучений із нього.

Тематичний аналіз називають методом ідентифікації, аналізу та звітування у межах (теми) даних. Він мінімально організовує та описує дані, визначені в деталях і тлумачить різні аспекти теми дослідження (Boyatzis, 1998). У такому варіанті його часто називають як метод аналізу. Крім того, його можуть називати - аналізом дискурсу або навіть контент-аналіз (Vermeer, Windsor, 2000) або не вказуючи конкретного методу, зазначати, що «обробка даних здійснювалася за допомогою якісного аналізу часто повторюваних тем» (Braun, Wilkinson, 2003. С. 30). Тематичний аналіз відрізняється від інших аналітичних методів, які намагаються описати дані за шаблоном і роблять акцент на досвіді, щоби зрозуміти його як реальність (Holloway, Todres, 2003). Отже тематичний аналіз є якісним методом, який дозволяє ідентифікувати, семіотизувати текст.

Через теоретичну необмеженість тематичний аналіз $є$ гнучким і корисним інструментом дослідження, який забезпечує водночас багатий і детальний, але складний обліковий запис даних. Проте відсутність чітких і стислих рекомендацій щодо застосування тематичного аналізу може призводити до втрати об’єктивності дослідження. Тому важливо знати потенційні ризики, яких слід 
уникати при проведенні тематичного аналізу, що забезпечує його об'єктивність, які його переваги та недоліки, як підбирати матеріал для тематичного аналізу.

Ключовим елементом тематичного аналізу є тема. Тема фіксує щось важливе щодо даних у зв'язку з досліджуваним питанням. Важливе значення для вирішення питання означення теми має те, що розглядається як шаблон, або який «розмір» може мати тема. В ідеалі існує декілька варіантів теми у цілому наборі даних, але більша кількість не обов'язково означає, що саме ця тема $\epsilon$ важливою. Немає чітких вказівок щодо частки набору даних, які повинні відображати ознаки теми. Тема може бути в окремих елементах даних. Питання про актуальність визначають шляхом аналізу тем і підтем. Фіксація тієї чи іншої теми не обов'язково залежить від кількісних показників, а визначається 3 точки зору того, чи вона фіксує щось важливе у зв'язку з загальним питанням дослідження (береться до уваги семантичний зміст). Наприклад, у дослідженні про представлення лесбійок та геїв на 26 ток-шоу (Clarke, Kitzinger, 2004), було визначено шість ключових тем. Ці теми не обов'язково були найпоширенішими в наборі даних - вони з'явилися між 2 і 22 з 26 розмов шоу, але разом вони охопили важливий елемент способу, яким лесбійки та геї «нормалізували» свої сім'ї в дискусіях на ток-шоу. У цьому випадку тематичний аналіз був задуманий у конкретному аналітичному питанні. Поширеність теми $\epsilon$ актуальною $\mathrm{i}$ може визначатися різними способами. Поширеність розраховувалась на рівні елемента даних (тобто тема з'являлася в будь-якому місці кожного окремого ток-шоу). В іншому випадку це могло б розраховуватися з точки зору кількості різних ораторів, які сформулювали тему, по всьому набору даних. Оскільки поширеність не була ключовою для зазначеного аналізу, то обиралася найпростіша форма.

Гнучкість тематичного аналізу полягає в тому, що можна визначати теми і поширеність їх кількома способами. Існують різні варіанти визначення поширеності теми, які не передбачають кількісної оцінки (на відміну від великого аналізу змісту, Wilkinson, 2000), наприклад: «більшість учасників» (Meehan, 2000), «багато учасників» (Taylor, Ussher, 2001) або «декілька учасників» (Braun, Gavey, McPhillips, 2003) актуалізують відповідну тему. Наприклад, агресія чоловіків щодо жінок зустрічається у розповідях учасників дослідження. Важливо визначити тип аналізу, який потрібно зробити. Наприклад, пропонується широкий тематичний опис усього набору даних, таким чином, що читач почує ключову тему агресії, яка буде проходити по сюжету усього тексту. У цьому випадку теми, які окреслюють, ідентифікують, кодують та аналізують, повинні бути точним відображенням усього набору даних, чітко ілюструвати ключові маркери чоловічої агресії чи інших поведінкових проявів. Це може бути ефективним методом тоді, коли вивчається недосліджений аспект поведінки, або з досліджуваними, чиї погляди, думки, уявлення не вивчалися раніше. Альтернативне використання тематичного аналізу полягає в тому, щоб надати більш детальний звіт про одну конкретну тему, наприклад агресію чоловіків, ії прояви, особливості переживання, можливо, причини виникнення. 
Важливим питанням у тематичному аналізі $є$ ідентифікація теми, яка може бути семантичною чи інтерпретаційною (Boyatzis, 1998). За допомогою семантичного підходу теми визначають на явному або поверхневому значенні даних, а дослідник нічого не шукає за межами того, що сказав досліджуваний або написав. Процес роботи передбачає вибір теми з опису, де дані були просто організовані, щоб показати шаблони в семантичному змісті і підсумок до тлумачення, де є спроба теоретизувати значення моделей (Patton, 1990). Наприклад, опитувані жінки озвучують переживання з приводу пережитої агресії зі сторони чоловіків. Це простіший спосіб ідентифікації теми, ніж інтерпретаційний, який вимагає від дослідника здатності до продуктивної семіотизації, визначенні прихованих смислів, тем. Тематичний аналіз на інтепретаційному рівні, навпаки, виходить за рамки семантичного змісту даних і спрямований на дослідження основних ідей, припущень та концептуалізацій, які дозволяють зрозуміти як і чому виник певний семантичний зміст. Наприклад, якщо ми уявимо наші дані у тривимірному вигляді як нерівномірний шматок желе i застосуємо семантичний підхід, то зможемо «описати» поверхню желе, його форму та сенс, тоді як інтерпретаційний підхід дозволяє визначити особливості, які надали йому такої форми та значення. Отже для інтерпретаційного тематичного аналізу розробка самих тем включає інтерпретаційну роботу та аналіз, що передбачає не просто опис, а й теоретизацію, концептуалізацію. Аналіз у рамках цієї останньої традиції, як правило, випливає з конструктивістської парадигми (Берра, 1995), і в цій формі тематичний аналіз збігається $з$ деякими формами «аналізу дискурсу» (який іноді спеціально називають «тематичний аналіз дискурсу» (Singer, Hunter, 1999; Taylor, Ussher, 2001), де широкі припущення, структури та значення теоретизовано як основу того, що насправді сформульовано в даних. Етапи проведення тематичного аналізу передбачають: 1) ознайомлення 3 даними, транскрипцію словесних даних; 2) створення вихідних кодів; 3) пошук тем; 4) аналіз змісту тем; 5) визначення назви тем; 6) підготовкуа звіту.

Висновки. Феміністську, зокрема постфеміністську методологію можна вважати альтернативною, у якій фокусується увага на досвіді гендеру особистості і проблематизується вибір методів його дослідження. Досвід жінок визначається як множинний, неоднорідний та багатомірний, що породжує потребу у формуванні нової теорії, методології і нових дослідницьких технік, які б були гендерно чутливими. У межах феміністської теорії сформувалися чотири епістемологічних вектори: феміністичний емпіризм, позиціонізм, постмодернізм і соціальний конструкціонізм. Багатомірність та множинність досвіду пояснюється у соціальному конструкціонізмі, де заперечується можливість проведення об'єктивного дослідження єдиного досвіду жінок, а зосереджується увага на конкретному досвіді. Відповідно, феміністична методологія, зокрема методологія конструктивістської перспективи, спрямована на відхилення кількісних та застосування якісних методів дослідження, що й зумовлено потребами дослідницької практики, зокрема отриманні суб'єктивних інтерпретацій. Якісні методи дослідження дозволяють визначати контексти досвіду, способи 
його створення, що надає досліднику знання про процес конструювання соціальної статі.

Тематичний аналіз є одним iз найбільш ефективних якісних методів, який дозволяє досліджувати гендерний досвід особистості i може застосовуватися в цілому ряді епістемологій та дослідницьких практик. Тематичний аналіз передбачає семантичний та інтерпретаційний підходи у визначенні тем. У межах конструктивістської парадигми застосовується інтерпретаційний підхід, який виходить за рамки семантичного означення змісту даних i спрямований на дослідження припущень та концептуалізацій, які дозволяють зрозуміти як і чому виник певний семантичний зміст. Тематичний аналіз, що використовується в межах конструктивістської парадигми, спрямований на 3'ясування соціально-культурних контекстів, у межах яких потрібно досліджувати досвід особистості, що у свою чергу, дозволяє визначати не сам досвід, а способи, особливості його конструювання. Саме особливості конструювання певного досвіду у жінок чи чоловіків викликає інтерес у сучасних дослідників, що і є перспективою подальших наукових розвідок авторки.

1. Смит Д. Социологическая теория. Методы патриархатного письма. Хрестоматия феминистских текстов / под ред. Е. Здравомысловой, А. Темкиной. Санкт-Петербург : Дмитрий Буланин, 2000. С. 32.

2. Braun Virginia, Clarke Victoria. Using thematic analysis in psychology. Qualitative Research in Psychology. 2006. № 3 (2). P. 77-101.

3. Butler Judith. Gender trouble: feminism and subversion of identity. New York, 1990. P. 170.

4. Gergen M. Feminist reconstructions in psychology: Narrative, gender \& performance. Thousand Oaks : Sage. 2001.

5. Gilligan C. In a different voice: Psychological theory and women's development. 2nd ed. Cambridge, MA : Harvard University Press, 1993.

6. Eagly A. H., Eaton A., Rose S. M., Riger S. \& McHugh M. C. Feminism and psychology: Analysis of a half-century of research on women and gender. American Psychologist. 2012. № 67 (3). P. 211-230.

7. Helgeson Viski S. The psyholody of gender. Carnegie Mellon University, 2012. P. 29-183.

8. Hesse-Biber S. N. Feminist Research Practice. Los Angeles : Sage Publications, 2013.

9. Hyde, J. Half the human experience. Lexington, MA : D. C. Health \& Company, 1996.

10. Kohli M. Roberts G., (Hg). Biographie und soziale Wirklichkeit. Stuttgart : Metzler, 1984. S. 18.

11. Matlin, M. The psychology of women. Fort Worth, TX : Harcourt Brace, 1996.

12. Percy, C. «Feminism», Gender and Psychology. London : Arnold, 1998. P. 27-40.

13. Review of Sandra Harding's Objectivity and Diversity : Another Logic of Scientific Research. Social Epistemology Review and Reply Collective 5. 2016. № 4. P. 60-64.

14. Sandra Harding «Introduction. Is there a Feminist Method?», in Sandra Harding, ed., Feminism and Methodology. Milton Keynes : Open University Press, 1987. P. 1-14.

15. Stanley L. and Wise, S. Breaking Out Again. Feminist Ontology and Epistemology. London : Routledge, 1993. P. 171. 


\section{References}

1. Smyt, D. (2000). Sotsyolohycheskaia teoryia. Metody patryarkhatnoho pysma. Khrestomatyia femynystskykh tekstov, 32. E. Zdravomyslovoi, A.Temkynoi (Eds.). Sankt-Peterburh: Dmytryi Bulanyn. [in Russian].

2. Braun Virginia, Clarke Victoria. (2006). Using thematic analysis in psychology. Qualitative Research in Psychology, 3 (2), 77-101. [in English].

3. Butler Judith. Gender trouble: feminism and subversion of identity. New York, 1990. P. 170.

4. Gergen, M. (2001). Feminist reconstructions in psychology: Narrative, gender \& performance. Thousand Oaks: Sage. [in English].

5. Gilligan, C. (1993). In a different voice: Psychological theory and womens development. (2nd ed.). Cambridge, MA: Harvard University Press. [in English].

6. Eagly, A.H., Eaton, A., Rose, S.M., Riger, S. \& McHugh, M.C. (2012). Feminism and psychology: Analysis of a half-century of research on women and gender. American Psychologist, 67 (3), 211-230. [in English].

7. Helgeson Viski, S. (2012). The psyholody of gender, 29-183. Carnegie Mellon University. [in English].

8. Hesse-Biber, S.N. (2013). Feminist Research Practice. Los Angeles: Sage Publications. [in English].

9. Hyde, J. (1996). Half the human experience. Lexington, MA: D.C. Health \& Company. [in English].

10. Kohli, M. Roberts, G., (Hg). (1984). Biographie und soziale Wirklichkeit, 18. Stuttgart: Metzler. [in German].

11. Matlin, M. (1996). The psychology of women. Fort Worth, TX: Harcourt Brace. [in English].

12. Percy, S. (1998). «Feminism», Gender and Psychology, 27-40. London: Arnold. [in English].

13. Review of Sandra Hardings Objectivity and Diversity: Another Logic of Scientific Research. (2016). Social Epistemology Review and Reply Collective 5, 4: 60-64. [in English].

14. Harding, Sandra. (1987). «Introduction. Is there a Feminist Method?», Sandra Harding (Ed.), Feminism and Methodology, 1-14. Milton Keynes: Open University Press. [in English].

15. Stanley, L. and Wise, S. (1993). Breaking Out Again: Feminist Ontology and Epistemology, 171. London: Routledge. [in English].

\section{УДК 316.6}

doi: 10.15330/psp.24.16-28

Світлана Литвин-Кіндратюк

\section{ІСТОРИКО-ЕВОЛЮЦІЙНИЙ ВЕКТОР СТУДІЙ РОЗВИТКУ ОСОБИСТОСТІ В СУЧАСНІЙ ПСИХОЛОГІЇ}

У статті розглянуто розвиток особистості в контексті сучасних історикоеволюиійних підходів у психології розвитку та соиіальній психології. Обстоюється доцільність збагачення методологічної бази изього пошуку на засадах ідей еволюиіонізму, методологій загальної, вікової, соиіальної психологї, сучасної міждисциплінарної платформи «наук про розвиток» у зарубіжній психології. Показано, щуо історіоризація розвитку особистості виходить з пріоритетності сощіально-історичної складової ицього процесу, щьо представлена лінією історіогенезу. Акиент на соціально-психологічному аналізі зазначеної лінії передбачає долучення до спектру сутнісних характеристик розвитку особистості контекстуальності, а також виокремлення концепту «між поколінна взаємодія» як «одиниці» аналізу изього проиесу.

Ключові слова: історико-еволючійний підхід, принџип розвитку, «одиниця» аналізу розвитку, покоління, між поколінна взаємодія, контекстуальність, історіогенез особисmocmi. 